\title{
Efektifitas Permainan Boneka Tangan Terhadap Penurunan Ketakutan Anak Hospitalisasi pada Usia Prasekolah (3-6 Tahun) di RSUD Dr. R. Koesma Kabupaten Tuban
}

\author{
Bernandha Hargi Dwitantya Putri ${ }^{*}$ Rinik Eko Kapti ${ }^{\star 凶}$, Tina Handayani*
}

\begin{abstract}
ABSTRAK
Hospitalisasi merupakan keadaan krisis anak sakit dan dirawat di rumah sakit yang dapat menimbulkan ketakutan pada anak. Peran perawat sangat penting dalam meminimalkan dampak hospitalisasi. Tujuan penelitian ini adalah untuk mengetahui efektifitas terapi permainan boneka tangan terhadap penurunan ketakutan anak pada usia prasekolah akibat hospitalisasi di RSUD Dr. R Koesma Kabupaten Tuban. Penelitian ini adalah penelitian quasi- experimental menggunakan teknik purposive sampling pada 36 responden. Perbedaan pre-test dan post-test pada kelompok kontrol maupun perlakuan dianalisis menggunakan uji statistik paired sample t- test dengan $95 \%(a=0,05)$. Pada kelompok kontrol, ketakutan anak sebelum dan sesudah perlakuan tidak mengalami penurunan. Pada kelompok perlakuan, ketakutan anak sebelum dan sesudah mengalami penurunan yang signifikan $(p=\ldots$...). Hasil post- test untuk kelompok kontrol dan perlakuan menggunakan uji independent $t$-test menunjukkan bahwa nilai $p=0,000$. Disimpulkan bahwa terdapat efektifitas terapi permainan boneka tangan dalam menurunkan ketakutan pada anak hospitalisasi usia prasekolah (3-6 tahun) di RSUD Dr. Koesma Tuban.
\end{abstract}

Kata Kunci: Anak prasekolah, Hospitalisasi, Ketakutan, Terapi bermain boneka tangan

\section{The Effectiveness of Hand Puppet Play to Reduce Fears in Hospitalized Preschool Children (3-6 Years) at Dr. R. Koesma Hospital Tuban}

\begin{abstract}
Hospitalization is a crisis situation when a child is sick and being hospitalized that can cause fears in children. The role of nurses is important to reduce the effect of hospitalization. The purpose of this study was to determine the effectiveness of hand puppet play to reduce fears in hospitalized children on preschool at Dr. $\mathrm{R}$ Koesma Hospital Tuban. This was a quasi-experimental with purposive sampling technique in 36 respondents. The differences in pre-test and post-test on control and also treatment groups were analized using paired sample t-test with convident interval level $95 \%(\alpha=0.05)$. In control group, the children showed no reducing fears before and after treatment. However, in the treatment group showed that fears in respondents were reduced significantly after treatment. The post-test results control and treatment groups using independent $t$-test showed $p$ value $=0.000$. So, it can be concluded that hand puppet play can reduce fears in hospitalized preschool children (3-6 years) at Dr. Koesma Hospital Tuban.
\end{abstract}

Keywords: Fears, Hand puppet play, Hospitalization, Preschool children

* Program Studi IImu Keperawatan, FKUB

\footnotetext{
$凶$ Program Studi IImu Keperawatan, Fakultas Kedokteran Universitas Brawijaya, Jalan Veteran Malang, 65145

E-mail: rinik.kapti@gmail.com
} 


\section{PENDAHULUAN}

Hospitalisasi merupakan suatu proses yang karena satu alasan yang berencana dan darurat, mengharuskan anak untuk tinggal di rumah sakit, menjalani terapi dan perawatan sampai pemulangannya kembali ke rumah. ${ }^{1}$ Saat dirawat di rumah sakit, anak harus menghadapi lingkungan yang asing, pemberi asuhan yang tidak dikenal, baik itu medis ataupun keperawatan. Sering kali mereka harus mengalami prosedur yang mengalami nyeri, kehilangan kemandirian dan berbagai hal yang tidak mereka ketahui. $^{2}$

Lingkungan fisik rumah sakit seperti bangunan atau ruang rawat, alat- alat, bau yang khas, pakaian putih petugas rumah sakit maupun lingkungan sosial seperti sesama pasien anak dan sikap petugas kesehatan itu sendiri, sehingga perasaan yang sering dialami oleh anak adalah perasaan cemas, tegang, nyeri, perasaan tidak menyenangkan dan rasa takut. ${ }^{3}$

Rasa takut anak- anak usia prasekolah terhadap keamanan tubuhnya lebih tinggi dibandingkan ketika pada usia sekolah. Ketakutan mereka tidak hanya berasal dari kurangnya pemahaman mereka akan tubuh, tetapi juga dilipat gandakan oleh imajinasi aktif mereka pada usia prasekolah. ${ }^{4}$

Anak sering menganggap prosedur medis invasif dengan ketakutan dan kecemasan, sehingga dapat menyebabkan anak kurang kooperatif terhadap perawat. Kondisi tersebut akan menyebabkan cemas dan takut pada anak yang akibatnya dapat menyebabkan gagalnya prosedur perawatan yang akan mereka dapatkan. ${ }^{5}$

Jika rasa takut tersebut berlangsung lama dan tidak teratasi maka akan menimbulkan reaksi kekecewaan pada orang tua yang menimbulkan sikap pelepasan pada anak sehingga anak mulai tidak peduli dengan ketidakhadiran orang tuanya dan lebih memilih untuk berdiam diri (apatis), menolak untuk diberikan tindakan dan yang paling parah akan menimbulkan trauma pada anak setelah keluar dari rumah sakit. ${ }^{6}$ Pengelolaan ketakutan, dapat mempengaruhi kenyamanan pada anak. ${ }^{7}$

Kenyamanan dan kesenangan anak dapat diperoleh dari bermain yang mempunyai nilai terapeutik sehingga adanya stres dan ketegangan dapat dihindari, mengingat bermain dapat menghibur diri anak terhadap dunianya. Bermain juga dapat mengembangkan fungsi kognitif anak dan sosialisasi anak. ${ }^{8}$

Terapi bermain merupakan salah satu teknik yang akan membantu menurunkan ketegangan emosional yang dirasakan anak. Secara bertahap respon psikis maupun fisiologis kecemasan dan ketakutan akan berkurang dan kepercayaan diri anak akan berkembang optimal pula. ${ }^{9}$ Melalui bermain, anak akan belajar tentang dunia dan kehidupan serta berhubungan dengan orang lain. Kesempatan bermain bagi anak seharusnya didapatkan dimana saja, termasuk ketika anak dirawat di rumah sakit. ${ }^{10}$

Terapi bermain boneka tangan berdampak terapeutik pada peningkatan komunikasi anak dan merupakan media untuk mengekspresikan perasaan yang mereka alami selama di rumah sakit. Seringkali anak terlalu takut untuk mengungkapkan perasaannya pada saat mengalami perawatan medis. Penggunaan boneka tangan pada anak- anak bertujuan untuk mengidentifikasi ketakutan dan kesalahpahaman tentang apa yang terjadi pada mereka. ${ }^{11}$

Dalam studi pendahuluan di RSUD Dr. R. Koesma Kabupaten Tuban, anak yang mengalami ketakutan saat hospitalisasi sekitar 40 anak pada usia 3- 6 tahun yaitu usia prasekolah. Saat perawat memulai prosedur invasif, banyak anak yang menangis saat disuntik, bahkan banyak anak yang memanggil- manggil orangtua mereka. 
Berdasarkan uraian di atas, dapat diketahui bahwa ketakutan pada anak yang mengalami hospitalisasi cukup besar dan memberikan dampak terhadap proses asuhan keperawatan. Perawat perlu mengetahui bagaimana cara menurunkan ketakutan pada anak yang dirawat di rumah sakit. Penelitian ini bertujuan untuk menegetahui seberapa besar efektifitas permainan boneka tangan terhadap penurunan ketakutan anak hospitalisasi usia prasekolah (3-6 tahun) di RSUD Dr. R Koesma Kabupaten Tuban.

\section{BAHAN DAN METODE}

Penelitian ini adalah penelitianquasyexperimental dengan pendekatan pretestpost testdesign withcontrol group. Populasi dalam penelitian ini adalah 40 anak berusia 3-6 tahun yang dirawat di Rumah Sakit Umum Daerah Dr. R Koesma Kabupaten Tuban. Sampel berjumlah 36 responden diambil menggunakan metode purposive sampling yang dibagi kedalam kelompok eksperimen dan kontrol,sehinggapada setiap kelompok terdapat 18 anak.

Kriteria inklusi pada penelitian ini yaitu anak mengikuti kegiatan permainan boneka tangan dari awal sampai akhir, mendapatkan persetujuan dari orang tua, anak yang di hospitalisasi pada hari kedua.

Variabel independen adalah media permainan boneka tangan. Instrumen penelitian adalah lembar kuisioner yang terdiri dari 19 pertanyaan. Pemberian skor adalah sebagai berikut, skor 4: selalu memperlihatkan perilaku ketakutan; skor 3: sering memperlihatkan perilaku ketakutan; skor 2: kadang-kadang memperlihatkan perilaku ketakutan; dan skor 1: tidak pernah memperlihatkan perilaku ketakutan. Skor terakhir dibagi menjadi 3 skor yaitu dengan skala interval yaitu rendah $=0-25$, sedang= 26-50, dan tinggi $=51-76$. Data yang diperoleh selanjutnya dianalisis dengan menggunakan uji $t$ berpasangan (paired sample t- test) dan uji t tidak berpasangan (independent $t$-test). Uji t berpasangan untuk mengetahui perubahan pre-test dan posttest pada kelompok kontrol dan eksperimen. Uji $t$ tidak berpasangan digunakan untuk mengetahui perbedaan hasil dari penurunan ketakutan hospitalisasi pada kelompok kontrol dan eksperimen.

\section{HASIL}

\section{Data Demografi Responden}

Distribusi data demografi responden pada penelitian ini berdasarkan usia yang disajikan pada Tabel 1 berikut:

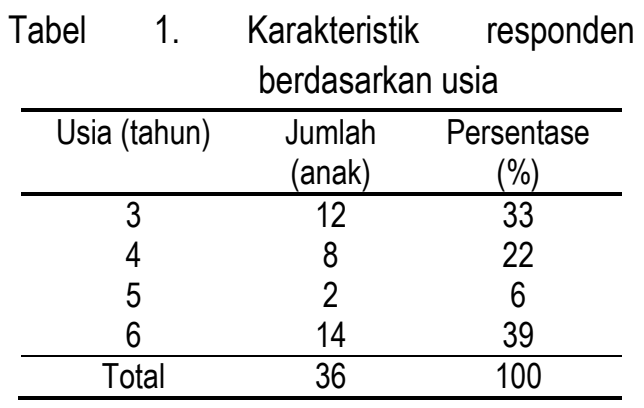

Distribusi data demografi responden berdasarkan jenis kelamin disajikan dalam Tabel 2 berikut:

Tabel 2. Karakteristik responden berdasarkan jenis kelamin

\begin{tabular}{ccc}
\hline Jenis kelamin & $\begin{array}{c}\text { Jumlah } \\
\text { (anak) }\end{array}$ & $\begin{array}{c}\text { Persentase } \\
(\%)\end{array}$ \\
\hline Perempuan & 18 & 50 \\
Laki- Laki & 18 & 50 \\
\hline Total & 36 & 100 \\
\hline
\end{tabular}

Distribusi data demografi responden berdasarkan lama rawat yang di tampilkan pada Tabel 3 berikut: 


\begin{tabular}{|c|c|c|}
\hline Tabel & \multicolumn{2}{|c|}{ berdasarkan lama rawat } \\
\hline $\begin{array}{l}\text { Lama rawat } \\
\text { (hari) }\end{array}$ & $\begin{array}{l}\text { Jumlah } \\
\text { (anak) }\end{array}$ & $\begin{array}{c}\text { Persentase } \\
(\%)\end{array}$ \\
\hline 4 & 17 & 47 \\
\hline 5 & 15 & 41 \\
\hline 6 & 4 & 11 \\
\hline Total & 36 & 100 \\
\hline
\end{tabular}

Analisis Data Ketakutan Sebelum dan Sesudah Terapi Permainan Boneka Tangan Pada Kelompok Kontrol

Pada Tabel 3 ditampilkan analisis data ketakutan yang dialami responden kelompok kontrol sebelum dan sesudah terapi.

Tabel 3. Analisis data ketakutan sebelum dan sesudah terapi pada kelompok konntrol.

\begin{tabular}{|ccccc}
\hline Variable & $\begin{array}{r}\text { Mean } \\
\text { Median }\end{array}$ & SD & Min-Maks & $\begin{array}{c}\text { 95\% Convident Interval } \\
\text { Lower - Upper }\end{array}$ \\
\hline Sebelum & $\begin{array}{r}49,06 \\
50,50\end{array}$ & 9,680 & $31-61$ & $44,24-53,87$ \\
Sesudah & $\begin{array}{r}48,94 \\
\text { I }\end{array}$ & 98,861 & $30-64$ & $44,04-53,85$ \\
& & & & \\
\hline
\end{tabular}

Berdasarkan tabel diatas diketahui bahwa nilai rata-rata sebelum terapi 49,06 , median 50,50 , nilai SD 9,680, nilai minimalmaksimal 31-61, nilai dengan $95 \%$ convident interval dengan nilai bawah-atas 44,2453,87 . Nilai rata-rata setelah terapi 48,94 , median 48,50 . Nilai SD 9,861 , nilai minimal 30 , nilai maksimal 64 , nilai dengan $95 \%$ convident interval dengan nilai bawah-atas 44,04-53,85.

Analisis Data Ketakutan Sebelum dan Sesudah Terapi Permainan Boneka Tangan pada Kelompok Eksperimen

Pada Tabel 4 ditampilkan analisis data ketakutan yang dialami responden kelompok eksperimen sebelum dan sesudah terapi.

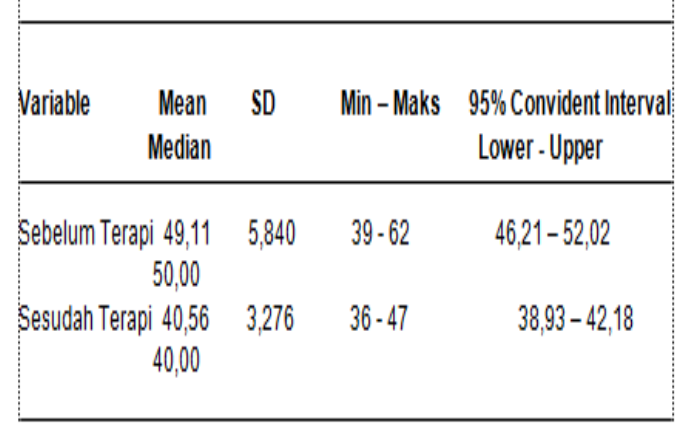

Berdasarkan tabel di atas diketahui bahwanilai rata-rata sebelum terapi 49,11 , median 50,00 . Nilai SD 5,840 , nilai minimal 39 , nilai maksimal 62 , nilai dengan $95 \%$ convident interval dengan nilai bawah-atas $46,21-52,02$. Nilai rata-rata setelah terapi 40,56 , median 40,00 . Nilai SD 3,276 , nilai minimal 36 , nilai maksimal 47 , nilai dengan $95 \%$ convident interval dengan nilai bawahatas 38,93- 42,18 .

\section{Hasil Uji t Berpasangan pada Kelompok Kontrol}

Pada Tabel 5 berikut ditampilkan hasil analisis paired $t$ test pada kelompok kontrol.

Tabel 5. Analisis paired $t$ test pada kelompok kontrol

\begin{tabular}{|lllllll|}
\hline Variable & Mean & SD & $\begin{array}{c}\text { STD Error } \\
\text { Mean }\end{array}$ & $T_{\text {hitun }}$ & df & P-value \\
\hline SkorPre-Test & 49,06 & 9,680 & 2,282 & 0,236 & 17 & 0,816 \\
Skor Post-Test & 48,94 & 9,861 & 2,324 & & & \\
SelisihPerbedaan & 0,11 & 1,997 & 0,471 & & & \\
\hline
\end{tabular}

Berdasarkan tabel diatas diketahui bahwa nilai signifikansi $P$ adalah 0,816 dengan $p>0,05(0,816>0,05)$, maka disimpulkan tidak ada penurunan ketakutan.

\section{Hasil Uji t Berpasangan pada Kelompok Eksperimen}

Pada Tabel 6 berikut ditampilkan hasil analisis paired $t$ test pada kelompok eksperimen. 
Tabel 6. Analisis paired t test pada kelompok eksperimen

\begin{tabular}{|lcccccc|}
\hline ariable & Mean & SD & $\begin{array}{c}\text { STD Error } \\
\text { Mean }\end{array}$ & $T_{\text {ntuv }}$ & df & P-value \\
\hline Skor Pre-Test & 49,11 & 5,840 & 1,376 & 5,434 & 17 & 0,000 \\
Skor Post-Test & 40,56 & 3,276 & 0,772 & & & \\
Selisih Perbedaan & 8,556 & 6,679 & 1,574 & & \\
\hline
\end{tabular}

Berdasarkan tabel diatas diketahui bahwa nilai signifikansi $p$ adalah 0,000 dengan nilai $p<0,05$, jadi ada penurunan ketakutan.

\section{Hasil Independen $t$ Test Skor Ketakutan Post-Test pada Kelompok Kontrol dan Kelompok Perlakuan}

Pada Tabel 7 berikut ditampilkan hasil analisis independen $t$ test pada kelompok kontrol dan eksperimen.

Tabel 7. Analisis independen $t$ test skor ketakutan post-test pada kelompok kontrol dan kelompok perlakuan

\begin{tabular}{|lccccc|}
\hline Kelompok & $\begin{array}{c}\text { Jumlah } \\
\text { Responden }\end{array}$ & Mean & SD & $\mathrm{t}$ & P.value \\
\hline Kontrol & 18 & $-0,11$ & 1,997 & $-5,887$ & 0,000 \\
Perlakuan & 18 & $-9,22$ & 6,225 & & \\
\hline
\end{tabular}

Berdasarkan tabel di atas diketahui bahwa skor ketakutan pada responden kelompok kontrol dan kelompok eksperimen didapatkan nilai $p<0,000$, jadi terdapat pengaruh terapi permainan boneka tangan terhadap penurunan ketakutan anak hospitalisasi pada usia prasekolah (3-6 tahun) di RSUD Dr. Koesma Tuban.

\section{PEMBAHASAN}

\section{Sebelum dan Sesudah Terapi Permainan Boneka Tangan pada Kelompok Kontrol}

Hasil sebelum perlakuan pada kelompok kontrol menunjukkan bahwa seluruh responden mengalami ketakutan, dengan nilai rata-rata 49,06. Hasil tersebut membuktikan bahwa pada hari kedua anak hospitalisasi, banyak stres yang dialami sehingga rasa ketakutan anak tinggi.Hal ini sesuai dengan penelitian sebelumnya yangmenyatakan bahwa pada hari kedua anak dirawat di rumah sakit, salah satu stressor yang menyebabkan anak mengalami ketakutan adalah perpisahan dengan orang tua. ${ }^{12}$ Anak mudah sekali menangis ketika masuk rumah sakit, menolak perhatian selain dari orang tua mereka. Mereka juga sering menangis ketika orang tua mereka meninggalkan ruangan dan anak tidak mau beraktivitas.

Hasil setelah perlakuan menunjukkan bahwa seluruh responden tetap mengalami ketakutan, dengan rata-rata nilai yang cukup tinggi yaitu 48,94. Dibandingkan dengan hasil sebelum perlakuan, hasil setelah perlakuan tetap menunjukkan skor ketakutan anak tinggi. Hasil tersebut menunjukkan tidak adanya perubahan skor ketakutan yang dialami responden pada hari keempat anak dirawat. Hal ini sesuai dengan penelitian Price dan Gwin (2008), yang menyatakan bahwa rutinitas selama di rumah sakit, prosedur medis yang dijalani seperti tirah baring, pemasangan infus dan lain sebagainya sangat mengganggu kebebasan dan kemandirian anak yang sedang dalam taraf perkembangan terutama pada usia prasekolah. ${ }^{13}$

Hasil penelitian lain menyatakan bahwa anak yang dirawat di rumah sakit cenderung merasa mempunyai perasaan yang tidak nyaman karena lingkungan rumah sakit yang tetap sama, yang membuat anak tidak dapat bebas bergerak sesuai keinginannya. ${ }^{14}$ Selama perawatan di rumah sakit, interaksi perawat dengan anak yang biasa dan selalu sesuai prosedur membuat anak mengalami ketakutan tersendiri. ${ }^{15}$ 


\section{Sebelum dan Sesudah Terapi Permainan Boneka Tangan pada Kelompok Eksperimen}

Hasil sebelum perlakuan pada kelompok eksperimen menunjukkan bahwa seluruh responden mengalami ketakutan,dengan rata-rata nilai yang cukup tinggi yaitu 49,11. Hal ini sesuai dengan penelitian Marwita (2013) yang menyatakan bahwa nilai hasil sebelum perlakuan pada kelompok perlakuan memiliki nilai ketakutan yang tinggi. ${ }^{16}$

Hasil setelah perlakuan menunjukkan bahwa hasil rata-rata tersebut menunjukkan perubahan tingkat ketakutan yang dialami responden apabila dibandingkan dengan sebelum perlakuan. Hasil tersebut membuktikan bahwa hospitalisasi merupakan stressor ketakutan tersendiri bagi anak.

Pada kelompok perlakuan secara umum semua responden mengalami penurunan skor ketakutan. Pemberian terapi bermain pada anak usia prasekolah (3-6 tahun) yang dihospitalisasi dapat menurunkan ketakutan akibat hospitalisasi dan akhirnya menjaga kondisi psikologis anak tetap baik. ${ }^{3}$ Bermain juga digunakan sebagai terapi dalam proses penyembuhan pasien anak karena diyakini mampu menghilangkan berbagai batasan, hambatan dalam diri, dan frustasi, karena bermain memiliki efek healing (penyembuhan).

\section{Perbedaan Sebelum dan Sesudah Perlakuan pada Kelompok Kontrol}

Perbedaan skor ketakutan anak hospitalisasi pada anak usia prasekolah (36 tahun) di RSUD Dr. R Koesma Tuban pada kelompok kontrol diketahui dari selisih rata- rata skor sebelum dan sesudah perlakuan yaitu 0,11 . Hasil uji t berpasangan menunjukkan $p=0,816(>0,05)$. Jadi dapat dinyatakan tidak ada efektifitas terapi permainan boneka tangan pada kelompok kontrol dalam menurunkan ketakutan anak hospitalisasi usia prasekolah (3- 6 tahun) di RSUD Dr. R Koesma Kabupaten Tuban.

Pada hasil sesudah perlakuan pada hari keempat anak dirawat di rumah sakit, secara umum seluruh responden tidak mengalami penurunan skor ketakutan. Hal ini menunjukkan adaptasi anak yang belum maksimal. Hal ini karena pada saat anak dirawat dan menjalani berbagai prosedur di rumah sakit, anak dengan rasa takut yang tinggi lebih banyak memperlihatkan perilaku negatif seperti menolak prosedur, menjerit keras, dan menyerang orang lain. ${ }^{17}$

Stressor yang dialami anak masih tetap sama yaitu lingkungan yang asing sehingga membuat anak tidak nyaman, perasaan berpisah dengan orang tua, komunikasi perawat yang monoton membuat anak mengalami ketakutan. Perpisahan dengan orang tua selama hospitalisasi membuat anak pasif saat di rumah sakit, sehingga anak membutuhkan dukungan yang lebih banyak. ${ }^{18}$ Lingkungan rumah sakit yang tetap sama atau tidak akrab yang mengakibatkan anak mengalami ketakutan. Komunikasi perawat yang kurang interaktif membuat anak merasa tidak nyaman sehingga anak tetap mengalami rasa takut saat di rumah sakit.

Selain itu, rumah sakit belum mempunyai intervensi yang spesifik untuk menurunkan ketakutan anak. Perawatan rumah sakit yang standar membuat anak mengalami ketakutan selama dirawat di rumah sakit. ${ }^{19}$ Rumah sakit perlu mempertimbangkan kebutuhan dan perkembangan anak, dengan mempersiapkan sarana di unit perawatan anak. Ketika mengembangkan ruang anak, perlu dipertimbangkan memisahkan ruang tindakan, dengan ruang perawatan. Hal ini agar tidak mengganggu dan membuat anak lain ketakutan, ketika sedang dilaksanakannya prosedur. Jadi tindakan prosedur rumah sakit tidak akan membuat 
anak merasa takut selama mengalami perawatan di rumah sakit.

Kurangnya informasi juga mengakibatkan anak tetap mengalami rasa takut saat di rumah sakit. Faktor kurangnya informasi yang didapat anak dan orang tuanya ketika menjalani hospitalisasi masih kurang. Jika anak mendapatkan informasi yang jelas terlebih dahulu sebelum mendapat prosedur rumah sakit, pada umumnya akan memiliki hasil yang baik. ${ }^{20}$ Sehingga ketakutan anak akan berkurang selama dan setelah tindakan.

\section{Perbedaan Sebelum dan Sesudah Perlakuan pada Kelompok Perlakuan}

Perbedaan skor ketakutan anak hospitalisasi pada anank usia prasekolah (36 tahun) di RSUD Dr. Koesma Tuban pada kelompok perlakuan diketahui adaperbedaan rata-rata selisih skor sebelum dan sesudah perlakuan pada anak yaitu 8,556 . Hasil uji $t$ berpasangan menunjukkan $p=0,000$ (> $0,05)$. Jadi dapat dinyatakan ada efektifitas terapi permainan boneka tangan pada kelompok perlakuan terhadap penurunan ketakutan pada anak hospitalisasi usia prasekolah (3 - 6 tahun) di RSUD Dr. Koesma Kabupaten Tuban.

Secara umum, seluruh responden mengalami penurunan skor ketakutan. Namunefektifitas terapi permainan boneka tangan ini berbeda pada setiap individu. Sesuai dengan hasil penelitian Mulyaningrum (2013) bahwa terapi permainan boneka tangan mempunyai nilai terapeutik pada peningkatan komunikasi anak. Boneka tangan juga merupakan media untuk mengekspresikan perasaan yang mereka alami selama di rumah sakit. Anak seringkali merasa takut untuk mengungkapkan perasaan mereka saat di rumah sakit. ${ }^{11}$ Penggunaan terapi permainan boneka tangan pada anak bertujuan untuk mengidentifikasi ketakutan anak tentang apa yang terjadi pada anak tersebut.

\section{Efektifitas Terapi Permainan Boneka Tangan terhadap Penurunan Ketakutan pada Anak Hospitalisasi Usia Prasekolah (3-6 tahun)}

Efektitas terapi permainan boneka tangan antara kelompok kontrol dan perlakuan terhadap penurunan ketakutan anak hospitalisasi usia prasekolah di RSUD Dr. Koesma Tuban diketahui dari hasil uji $t$ tidak berpasangan yang menunjukkan nilai $p=0,000(<0,05)$. Ada efektifitas terapi permainan boneka tangan untuk menurunkan ketakutan anak hospitalisasi usia prasekolah (3-6 tahun) di RSUD Dr. R. Koesma Tuban.

Dari uji hipotesis diketahui bahwa terdapat pengaruh terapi permainan boneka tangan terhadappenurunan skor ketakutan anak hospitalisasi karena ada penurunan ketegangan emosional. Hal ini karena selama anak dirawat dan menjalani berbagai prosedur di rumah sakit, anak dengan rasa takut yang tinggi lebih banyak memperlihatkan perilaku negatif seperti menolak prosedur, menjerit keras, dan menyerang orang lain daripada anak yang memiliki rasa takut rendah. ${ }^{11}$

Adanya stimulus dari luar tersebut merangsang PFC (cortex prefrontal) untuk menerima rangsangan. PFC ini terletak pada lobus frontalis yang mengatur fungsi-fungsi eksekutif seperti pengambilan keputusan, perencanaan, organisasi atau manajemen dan yang terpenting adalah memproses setiap informasi yang masuk melalui panca indera lalu kemudian mempersepsi informasi tersebut. Hasil persepsi dari PFC akan menentukan respon yang akan diberikan oleh tubuh. PFC ini biasa diandalkan sebagai CEO dari otak kita dan bagian kreatif dalam pikiran kita (inner mind). Amygdala akan memberikan respon sesuai hasil persepsi dari PFC yang selanjutnya akan memberikan sinyal ke hipothalamus untuk memberikan respon fisik dan sellular dalam tubuh. ${ }^{20}$ Respon fisik dapat berupa 
peningkatan detak jantung, peningkatan tekanan darah, produksi keringat, penegangan otot, penajaman sensasi, dan dilatasi pupil. ${ }^{11}$

Penggunaan media boneka tangan menolong anak untuk bernalar dan membentuk konsep tentang segala sesuatu yang berhubungan dengan objek, baik ukuran, bentuk, berat, maupun manfaatnya. Media boneka tangan berupa auditory, kinestetik dan visual. Melalui cerita boneka tangan yang diberikan kepada anak, akan memberikan pengalaman bagi anak, memungkinkan anak untuk menganalisis cerita boneka tangan, membangkitkan motivasi anak, serta rasa ingin tau isi cerita boneka tangan. Boneka tangan memberikan informasi yang diperoleh anak lebih jelas, boneka tangan membantu anak memperjelas suatu masalah yang mereka hadapi saat dirawat di rumah sakit. ${ }^{22}$

Selain itu, perasaan anak juga dapat diekspresikan melalui boneka tangan. Melalui cerita boneka tangan anak mampu mengungkapkan rasa sakitnya saat menjalani prosedur rumah sakit dan bertanya apakah tindakan prosedur yang dihadapinya tersebut menyakitkan atau tidak. ${ }^{19}$ Terapi permainan boneka tangan mempunyai nilai terapeutik pada peningkatan komunikasi anak. ${ }^{11}$

Anak seringkali merasa takut untuk mengungkapkan perasaan mereka saat di rumah sakit. Pengaruh boneka yangan dijelaskan oleh Pratiwi (2012) dalam penelitiannya bahwa dengan adanya terapi permainan boneka tangan dapat membantu anak untuk menurunkan ketegangan emosional anak. Dengan terapi permainan boneka tangan yang bertahap, respon psikis dan fisiologis kecemasan dan ketakutan anak akan berkurang sehingga kepercayaan diri anak akan lebih meningkat dan berkembang dengan optimal. ${ }^{9}$ Boneka tangan lebih mudah dipahami dan dimengerti oleh anak, sehingga saat anak melakukan terapi permainan boneka tangan ini, anak mengerti tentang situasi yang sedang dihadapinya.

\section{KESIMPULAN}

Kesimpulan yang diperoleh dari penelitian ini yaitu terapi permainan boneka tangan efektif terhadap penurunan ketakutan anak hospitalisasi pada usia prasekolah (3-6 tahun) di RSUD Dr. R. Koesma Kabupaten Tuban.

\section{SARAN}

Perlu adanya pemberian terapi bermain pada anak hospitalisasi dengan kegiatan bermain boneka tangan dan menjadikannya bagian dari intervensi dalam asuhan keperawatan anak di RSUD Dr. R. Koesma Kabupaten Tuban.

\section{DAFTAR PUSTAKA}

1. Supartini Y. Buku Ajar Konsep Dasar Keperawatan Anak.Ester M (Editor). Jakarta: Penerbit EGC. 2004.

2. MurtutikL dan Wahyuni. Hubungan Frekuensi Hospitalisasi Anak dengan Kemampuan Perkembangan Motorik Kasar pada Anak Prasekolah Penderita Leukimia di RSUD Dr. Moewardi. Jurnal IImu Keperawatan Indonesia. 2013; 6(3):2.

3. Yusuf M dan SyamsuddinA. Pengaruh Terapi Bermain terhadap Kondisi Psikologis Anak Usia Prasekolah yang Mengalami Hospitalisasi di Rumah Sakit Umum Daerah Dr. Zainoel Abidin Banda Aceh. Jurnal Kesehatan IImiah Nasuwakes. 2013; 6(2):2.

4. Bastable SB. Perawat sebagai Pendidik. Widyastuti $\mathrm{P}$ (Editor). Jakarta: Penerbit EGC. 2002.

5. Muttaqin A. Buku Ajar Asuhan Keperawatan dengan Gangguan Sistem 
Persarafan. Jakarta: Salemba Medika. HIm 222. 2008.

6. Pravitasari A dan Edi B. Perbedaan Tingkat Kecemasan Pasien Anak Usia Prasekolah Sebelum dan Sesudah Program Mewarnai.2012;1(1):16-21.

7. Fung E. Psychosocial Management of Fearsof Needles in Children. The Official Journal of the World Federation of Hemophilia. 2009; 15(2):635-636. doi: 10.1111

8. Pratiwi YS. Penurunan Tingkat Kecemasan Anak Rawat Inap dengan Permainan Hospital Story di RSUD Kraton Pekalongan. IImiah Kesehatan. 2012;5(2).

9. Hidayat AAA. Pengantar IImu Kesehatan Anak untuk Pendidikan Kebidanan. Jakarta: Salemba Medika. 2008.

10. Fatmawati E, Samiasih, Amin, dan Pawestri. Perawatan Terapi Bermain oleh Mahasiswa Profesi Ners di Bangsal Perawatan Anak RSUP DR.Kariadi Semarang. 2013;1(3):2.

11. Mulyaningrum DA. Pengaruh Edukasi dengan Boneka Tangan terhadap Kecemasan Anak yang Menderita Kanker di INSKA RSUP Dr. Sardjito Yogyakarta. 2013.

12. Hooshmand A, Keshavarz F, and BaghadrsariansA. The Impact of Play Therapy on Developmental Fearsamong Preschoolers. International Research Journal of Applied and Basic Sciences. 2013; 4(7):1740-1745.

13. Price DI dan Gwin JF. Pediatric Nursing an Intoductory Text.10 $10^{\text {th }}$ edition. Philadelphia: Saunders-Elseiver. 2008.

14. Westwood N. The Health-Care Environment Through the Eyes of $\mathrm{A}$ Child--Does It Soothe or Provoke Fears ?. 2012; 18(1):7-11. doi: 10.1111/j.1440172X.2011.01995.

15. Lucia A dan Juan LC. The Experience of Hospitalized Children Regarding Their
Interactionswith Nursing Professionals. Rev Latino-Am Enfermagem. 2011; 19(6):1429-1436.

16. Marwita F. Pengaruh Pendidikan Kesehatan pada Orang tua terhadap Tingkat Kecemasan Orang Tua pada Anak yang di Hospitalisasi di RSUD Dr.Achmad Mochtar Bukit Tinggi. 2013.

17. Yoo H, RNaMS, Kim S, Hur HK,dan Kim HS. The Effects of An Animation Distraction Intervention on Pain Response of Preschool Children During Venipuncture.2011; 24:94-100. doi: :10.1016/j.apnr.2009.03.005

18. Utami Y. Dampak Hospitalisasi terhadap Perkembangan Anak. Jurnal imiah Widya. 2014;2(2):2.

19. Hernandez M, Thoma S, Evans A, Jesse $P$, Lian B, TingleC. The Effects of Medical Play on Reducing Fears, Fears, and Procedure Distress in School-Aged Children Going to Visit the Doctor. 2011.

20. Gordon JB, Perrin M, Jackson A, Sandstrom A, Sheehan S. Child and Parental Surveys about Prehospitalization Information Provision. Child: Care, Health and Development. 2011; 37(5):727-733. doi: 10.1111/j.1365-2214.2010.01190.

21. Etkin. Emotional Control Circuit of Brain Fears Response Discovered. 2006.

22. Sudaniti TW. Peningkatan Keterampilan Bercerita Siswa Kelas VIIB SMP Negeri 1 Prambanan Sleman dengan Menggunakan Media Boneka Tangan.Yogyakarta:Universitas Negeri Yogyakarta. 2011.

23. Yusuf $M$ dan Syamsuddin A. Pengaruh Terapi Bermain terhadap Kondisi Psikologis Anak Usia Prasekolah yang Mengalami Hospitalisasi di Rumah Sakit Umum Daerah Dr. Zainoel Abidin Banda Aceh. Jurnal Kesehatan IImiah Nasuwakes. 2013; 6(2):2. 